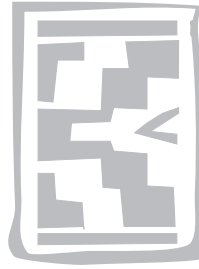

\title{
Studies on effects of lactose on experimental Trypanosoma vivax infection in Zebu cattle. 2. Packed cell volume
}

\author{
M.Y. FATIHU ${ }^{1 *}$, S. ADAMU ${ }^{1}$, I.A. UMAR ${ }^{2}$, N.D.G. IBRAHIM ${ }^{1}$, L.O. EDUVIE ${ }^{3}$ \\ and K.A.N. ESIEVO'
}

\begin{abstract}
FATIHU, M.Y., ADAMU, S., UMAR, I.A., IBRAHIM, N.D.G., EDUVIE, L.O. \& ESIEVO, K.A.N. 2008. Studies on effects of lactose on experimental Trypanosoma vivax infection in Zebu cattle. 2. Packed cell volume. Onderstepoort Journal of Veterinary Research, 75:181-187

The ability of intravenously administered lactose in normal saline to prevent a decline in packed cell volume (PCV) during experimental trypanosomosis was studied in Zebu cattle. During the lactose infusion period, the PCV was stable up to Day 5 post-infection (p.i.) in a lactose-infused group, compared to that in an uninfused group in which the PCV dropped significantly $(P<0.05)$ as shown by the values of cumulative percentage change. Furthermore the mean rate of change in PCV was significantly $(P<0.05)$ higher in the uninfused group relative to the lactose-infused group during the same period. While the PCV fell markedly in the lactose-infused group a day after lactose infusion was stopped (Day 13 p.i.), subsequent PCV values were significantly $(P<0.05)$ higher compared to those in the uninfused group, up to the end of experiment on Day 17 p.i. However the mean rates of change in PCV did not vary significantly $(P>0.05)$ between the groups during the period in which lactose infusion was stopped. The mean levels of parasitaemic waves and parasitaemia were higher, more prolonged and more frequent in the lactose-infused group. It was inferred that the lactose was able to prevent an early onset of anaemia in the Trypanosoma vivax-infected Zebu cattle.
\end{abstract}

Keywords: Anaemia, cattle, infusion, lactose, packed cell volume, Trypanosoma vivax

\section{INTRODUCTION}

The principal factor involved in the pathology of African trypanosomosis in humans and animals is anaemia (Hornby 1921; Murray 1974; Dargie 1978; Luckins 1992) although the mechanisms through which the anaemia occurs remain open. However,

* Author to whom correspondence is to be directed. E-mail: myfatihuy@yahoo.com

1 Department of Veterinary Pathology and Microbiology, Ahmadu Bello University, Zaria, Nigeria

2 Department of Biochemistry, Ahmadu Bello University, Zaria, Nigeria

3 National Animal Production Research Institute, Ahmadu Bello University, Zaria, Nigeria

Accepted for publication 21 April 2008-Editor haemolysis is involved in the early stage of the infection (Mamo \& Holmes 1975; Holmes \& Jennings 1976) as a result of erythrophagocytosis by the mononuclear phagocyte (monocyte-macrophage) system (Jennings, Murray, Murray \& Urquhart 1974; Holmes \& Jennings 1976; Saror 1980). Immunologic mechanisms also play a role in the trypanosomosisinduced anaemia (Fiennes 1950; Woodruff, Ziegler, Hathaway \& Gwata 1973; Kobayashi, Tizzard \& Woo 1976), which renders the erythrocytes more susceptible to phagocytosis.

Trypanosomes produce sialidase, which is a potent enzyme (Esievo 1979; Esievo 1983; Pereira 1983; Nok \& Balogun 2003) that cleaves off the membrane surface sialic acid of erythrocytes which results in a shortened life-span of erythrocytes by exposing the 
galactose of the cell membrane (Jancik \& Schauer 1974; Durocher, Payne \& Conrad 1975; Mamo, Holmes \& Lemma 1977) which readily binds to lectin on the surface of Kupffer cells and other macrophages, resulting in erythrophagocytosis (Kuster \& Schauer 1981; Muller, Schroder, Franco, Shukla \& Schauer 1983; Kelm, Jibril, Lee, Yoshino \& Schauer 1986a; Kelm, Shukla, Paulson \& Schauer 1986b).

Studies on the erythrocyte surface sialic acids of trypanotolerant N'Dama cattle and the more susceptible Zebu cattle have demonstrated the role these acids play in trypanotolerance, as both calves and adult N'Dama have a significantly higher erythrocyte surface sialic acid concentration with an additional band than that of Zebu cattle. This suggests a more resistant erythrocyte surface to the anaemia of trypanosomosis (Esievo, Jaye, Andrew, Ukoha, Alafiyatayo, Eduvie, Saror \& Njoku 1990).

Reports have also shown that lactose prevents binding between the lectin of Kupffer cells and the exposed galactose of the membrane surface of erythrocytes (Kolb \& Kolb-Bachofen 1978; Kolb, Vogt, Herbertz, Cornfield, Schauer \& ShlepperSchafer 1980; Schlepper-Schafer, Kolb-Bachofan \& Kolb 1981; Kelm \& Schauer 1986). This inhibition of binding prevents erythrophagocytosis of desialylated erythrocytes as has been demonstrated in vivo in rabbits injected with asialofetuin and lactose (Muller, Franco \& Schauer 1981), and in cattle infused with lactose during acute trypanosomosis (Ibrahim 1997). The packed cell volume (PCV) is one of the most valuable technique for determination of the percentage of the cellular components of blood in the clinical laboratory (Coles 1986). This study was conducted to determine the ability of lactose to prevent anaemia in $T$. vivax-infected cattle, based on variations in $\mathrm{PCV}$.

\section{MATERIALS AND METHODS}

Eight White Fulani Zebu bulls, aged between 3 and 4 years and weighing between 120 and $200 \mathrm{~kg}$ were purchased from Anchau in the Kubau Local Government Area of Kaduna State which is located in a tsetse fly-free zone of northern Nigeria, and kept and treated as described by Fatihu, Adamu, Umar, Ibrahim, Eduvie \& Esievo (2008a). The isolation of the parasite abd the preparation of the lactose infusion solution have been described by the same authors (Fatihu et al. 2008a).

The experimental animals were placed into two groups of four animals each. They were housed separately and blood samples were collected from each bull for 2 consecutive days prior to infection, to establish the baseline haematological data. The groups were treated as follows:

\section{Group A}

Each bull in this group was infected with $3 \times 10^{6} \mathrm{~T}$. vivax primary isolate by jugular venepuncture using $6 \mathrm{ml}$ of the donor bull's blood.

\section{Group B}

The bulls in this group were infected as were those in Group A. In addition, lactose infusion commenced immediately at a dose of $0.5 \mathrm{~g}$ per $\mathrm{kg}$ body mass, 3 times daily at $4 \mathrm{~h}$ intervals for 12 days.

\section{Sample collection and analysis}

Every morning $2 \mathrm{ml}$ of blood were collected from each of the eight bulls by jugular venepuncture into McCartney bottles containing ethylenediamine tetra-acetic acid (EDTA). A daily determination of their PCVs was done using the haematocrit method (Coles 1986) and parasitaemia was monitored and estimated by the dark ground/phase contrast buffy coat technique-DG (Murray, Trail, Turner \& Wissocq 1983).

\section{Data analysis}

Variations in the PCV values of the bulls in the two groups were analysed through time series (values at different periods or point in time) that consisted of two separated periods, namely during lactose infusion (DL), from the day of infection to Day 12 p.i. and after lactose infusion (AL), from Days 13 to 19 p.i. The percentage change ( $X \%)$ in PCV values recorded daily for each bull was calculated as follows:

$$
\mathrm{X} \%=\frac{\mathrm{PCV}_{\mathrm{t}}-\mathrm{PCV}_{\mathrm{t}-1}}{\mathrm{PCV}_{\mathrm{t}-1}}
$$

where, $P C V_{t}$ refers to the PCV for any given day, $t$, while $P C V_{t-1}$ is the value for the preceding day. The mean cumulative percentage change (CPC) in PCV for each group was calculated separately for the respective periods ( $D L$ and $A L$ ) from the mean daily percentage changes.

The rate of change in PCV for the two infected groups for the periods $\mathrm{DL}$ and $\mathrm{AL}$ were determined by the cumulative sums of difference (Chatfield 1983). The difference (dt) between a given PCV value $\left(\mathrm{PCV}_{\mathrm{t}}\right)$, and the value on the day preceding 
the commencement of the given period $\left(\mathrm{PCV}_{\mathrm{a}}\right)$ was obtained by:

$$
d_{t}=P C V_{t}-P C V_{a}
$$

The PCV $\mathrm{P}_{\mathrm{a}}$ for $\mathrm{DL}$ is the PCV on Day 0 and that of $\mathrm{AL}$ is PCV on Day 12 p.i.

The cumulative sums of difference $\left(C_{t}\right)$ from $\mathrm{PCV}_{a}$ (for the specific period) was calculated from the mean difference on each day using:

$$
\mathrm{C}_{\mathrm{t}}=\overline{\mathrm{d}}_{\mathrm{t}}+\overline{\mathrm{d}}_{\mathrm{t}-1}
$$

Where $\bar{d}_{t}$ and $\bar{d}_{t-1}$ are the mean differences for day $t$ and the pervious day, respectively.

A regression line was drawn (Harper 1991) from the plots of $C_{t}$ values versus time (in days). The expected mean differences from $\mathrm{PCV}_{\mathrm{a}}$ during the periods $D L$ and $A L$ were determined from the $C_{t}$ regression lines. The rate of change in PCV was calculated as the expected mean change divided by time (in days) and expressed as units per day. The rate of change was also plotted versus time (in days).

The data was summarized and given as means \pm standard error of means (SEM). The Student's $t$-test (Philips 1978) was used to compare two means for any significant difference.

\section{RESULTS}

\section{Parasitaemia}

The parasites were first detected in circulation on the third day p.i. in the animals in both groups. The first peak of parasitaemia occurred on Days 4 and 6 p.i. in Groups B (lactose-infused) and A (uninfused) bulls, respectively. The level of parasitaemia was higher throughout the duration of the experiment in Group B. The highest parasitaemic peaks were recorded on Day 6 p.i., while the lowest parasitaemia was observed on Day 9 p.i. in both groups when no parasites were detected in Group A. More frequent and prolonged parasitaemic peaks were observed in Group B, even when lactose infusion had stopped. Furthermore, the level of parasitaemia in Group B did not fall below the initial level when trypanosomes were first detected in blood, on Day 3 p.i. (Fig. 1).

\section{Variations in packed cell volume during lactose infusion (DL)}

As lactose infusion to Group B commenced immediately after infection (Day 0), the mean PCV improved by $+0.35 \pm 2.53 \%$ whereas the PCV significantly
$(P<0.05)$ dropped in the uninfused (group A) bulls by $-10.61 \pm 7.87 \%$ on Day 1 p.i. The changes in PCV values up to Day 5 p.i. showed that Group B experienced a lower fall in PCV, with a cumulative percentage change $(C P C)$ of $-2.69 \pm 1.1 \%$ when compared to a CPC of $-13.76 \pm 2.24 \%$ in group $A$ (Table 1, DL), which was statistically significant $(P<$ 0.05).

Furthermore, the $C_{t}$ regression for Group B was located above that of Group A as depicted in Fig. 2 (DL). This indicates that the fall in PCV was relatively reduced in Group B, as is further illustrated by the rates of change in PCV (Fig. 3, DL), which appeared less negative than in Group A.

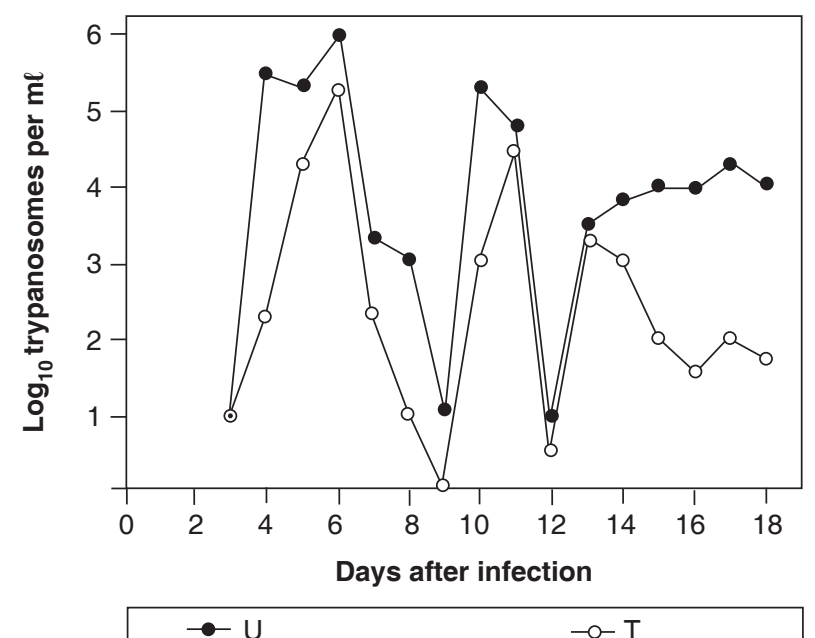

FIG. 1 Mean parasitaemia in Trypanosoma vivax-infected Zebu bulls treated $(T)$ and untreated $(U)$ with lactose

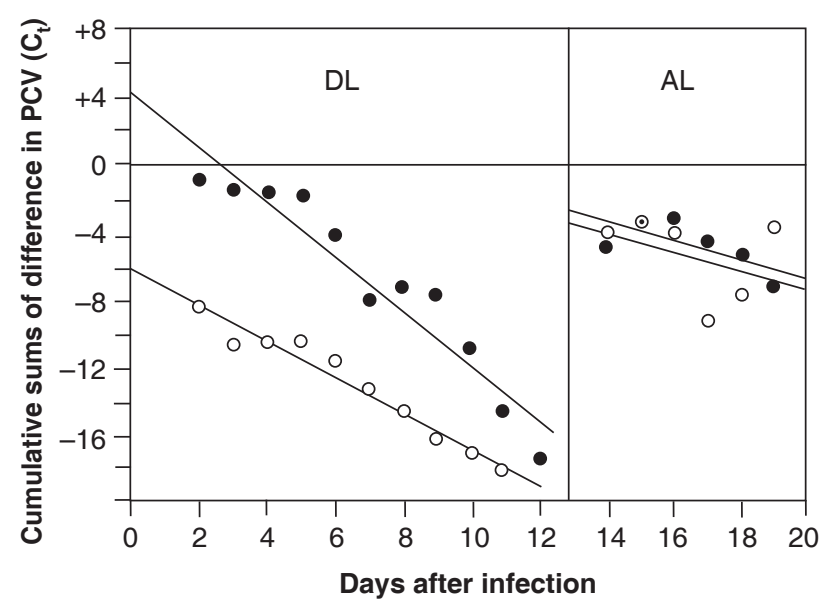

$$
\multimap \mathrm{U} \multimap \mathrm{O}
$$

FIG. 2 Cumulative sums of difference in PCV of Trypanosoma vivax-infected Zebu bulls treated $(\mathrm{T})$ and untreated $(\mathrm{U})$ with lactose during (DL) and after $(A L)$ treatment 


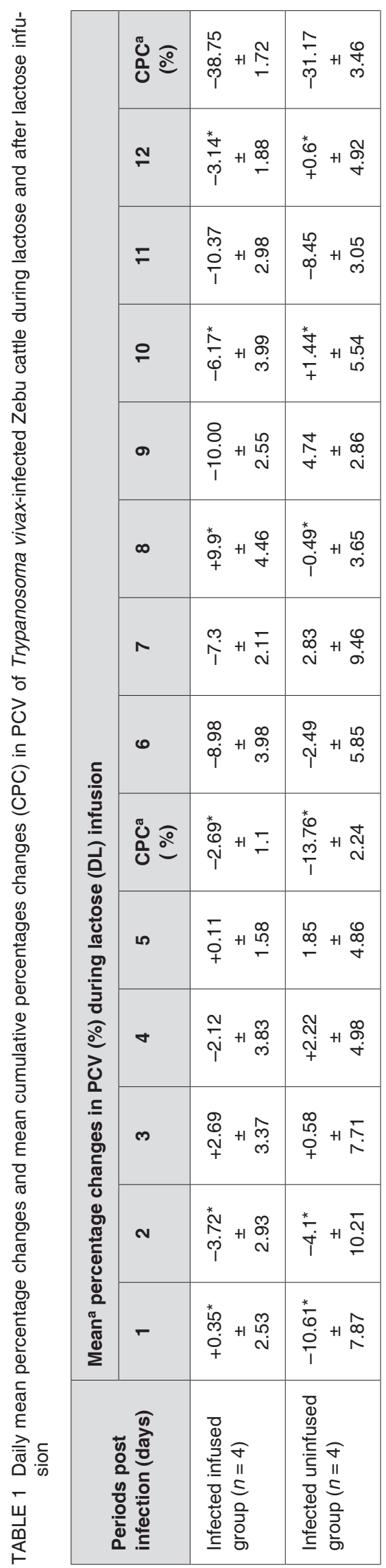

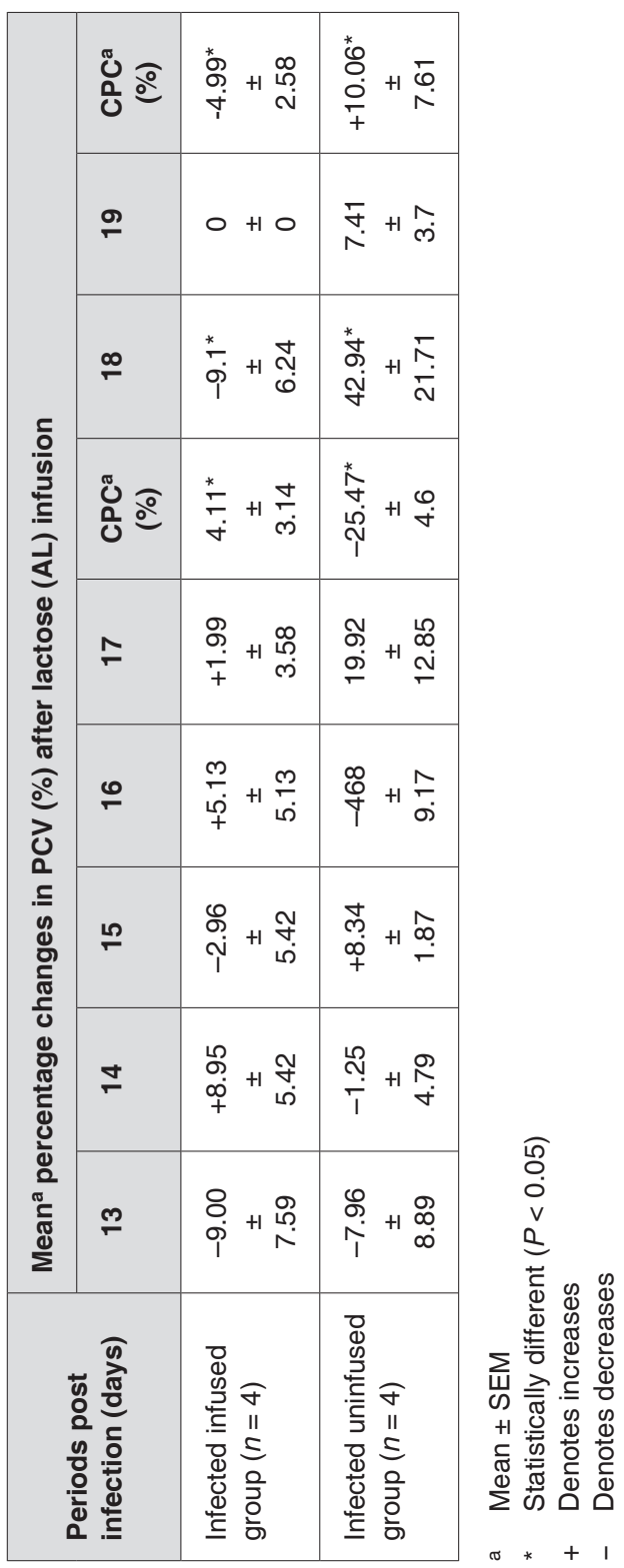


TABLE 2 Mean rates of change in PCV of Trypanosoma vivax-infected Zebu cattle during lactose (DL) and after (AL) lactose infusion

\begin{tabular}{|l|l|l|}
\hline \multirow{2}{*}{ Groups } & \multicolumn{2}{|l|}{ Meana rates of change in PCV (units per day) } \\
\cline { 2 - 3 } & DL & AL \\
\hline Infected, infused $(n=4)$ & $-0.08^{*} \pm 0.17$ & $-1.15 \pm 0.13$ \\
\hline Infected, uninfused $(n=4)$ & $-2.25^{\star} \pm 0.24$ & $-1.37 \pm 0.1$ \\
\hline
\end{tabular}

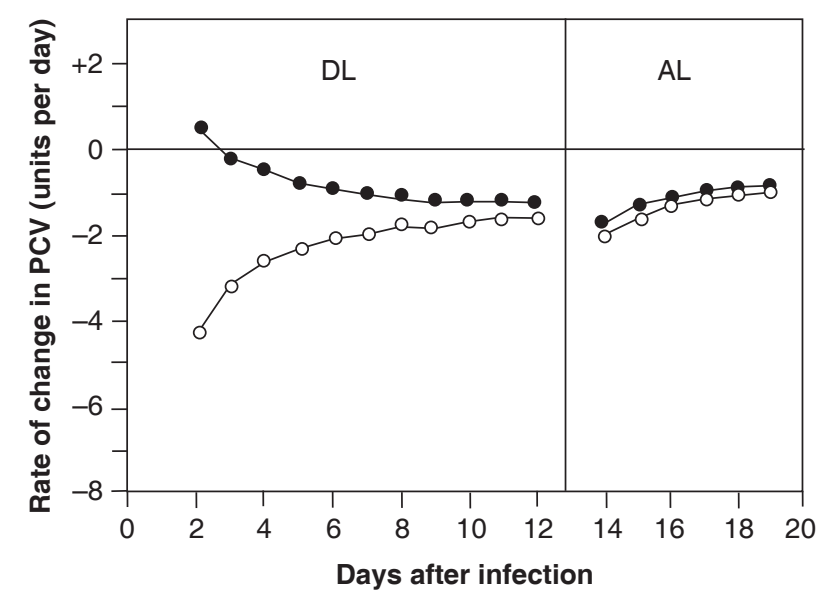

$\rightarrow U$

FIG. 3 Rates of change in PCV of Trypanosoma vivax-infected Zebu bulls treated $(\mathrm{T})$ and untreated $(\mathrm{U})$ with lactose, during $(\mathrm{DL})$ and after $(\mathrm{AL})$ lactose treatment

During the period of lactose infusion, the means rates of decrease in PCV (Table 2) were significantly $(P<0.05)$ higher in Group A bulls.

\section{Variations in packed cell volume after lactose infusion (AL)}

A day after lactose infusion was stopped (Day 13 p.i.) the mean PCV in the lactose-infused (Group B) bulls fell by a mean of $9.0 \pm 7.59 \%$ from the value of the previous day, which was higher compared to the uninfused (Group A) bulls (Table 1, AL). However, subsequent $\mathrm{PCV}$ values were significantly $(P<0.05)$ higher in Group B and by Day 5, AL (Day 17 p.i), a $\mathrm{CPC}$ of $+4.11 \pm 3.14 \%$ was obtained compared to CPC of $-25 \pm 4.6 \%$ in Group A. At the end of the ALperiod, (Day 19 p.i.) however the PCV significantly $(P<0.05)$ rose in Group A, above that of Group B. The cumulative sums of difference $\left(C_{t}\right)$ for this period (Fig. 2, AL) showed that the curve of Group A remained below that of Group B, although the gap has been narrowed when compared to the DL-period. Similarly, the profiles of rates of change in PCV (Fig. $3, A L)$ further indicates that the rate of decrease in
PCV, although relatively higher in Group A, remained narrow compared to that of Group B. The mean rates of change in PCV (Table 2) showed that the PCV of Group A dropped insignificantly $(P>0.05)$ during the period, relative to that of Group B.

\section{DISCUSSION}

The occurrence of the first peak of parasitaemia in the lactose-infused group was on Day 4 p.i. while that of the uninfused group was on Day 6 p.i., even though trypanosomes were first detected on the same day in both groups. The more frequent and higher parasitaemic peaks, and the more persistent, detectable parasitaemia observed in the lactose-infused group were attributable to the presence of lactose in the plasma. Since glucose and galactose, which are the primary constituents of lactose, have been identified in abundance in some trypanosomes (Von Brand 1973; Cross \& Johnson 1976) and the glucose consumption of African trypanosomes is high; corresponding to about $50-100 \%$ of their dry mass per hour (Von Brand 1973), their affinity to the infused lactose and its possible utilization could account for the persistent and higher parasitaemia observed in the T. vivax-infected, lactose-infused bulls as similarly observed by Umar, Omage, Shugaba, Igbokwe, Kwanashie, Agbede, Saror \& Esievo (1998). Perhaps the trypanosomes contain $\beta$-galactosidase or its equivalent that can cleave lactose into the glucose and galactose monosaccharides for their utilization.

In addition, lactose possibily re-enforces the antigenic glycoprotein coat of $T$. vivax because trypanosomes such as Trypanosoma cruzi (Von Brand 1973) and Trypanosoma brucei (Cross \& Johnson 1976) are known to contain glucose and galactose among other polysaccharides in their membrane coats.

The remission and recrudescence of parasitaemia observed in the groups were marked features of both natural and experimental infection of mammals 
with various species of subgenus Trypanozoon. The antigenic variation of the parasites and the hosts' humoral and cell-mediated immune responses play a role in this mechanism (Vickerman, Sless, Wendy \& Edwards 1976).

The pattern of decrease in PCV of the T. vivax-infected, lactose-infused bulls was modified by the lactose infusion, which significantly prevented the fall in PCV up to Day 5 p.i. despite the occurrence of a persistent and higher parasitaemia in this group, during the period. However, the fall in PCV from Day 6 p.i. could also be associated with the haemodilution caused by to the infused lactose or the combined effects of an overwhelming infection and lactose infusion. Lactose was able to stabilze the PCV during the infusion period (DL) as shown by the mean rate of change in PCV which was significantly higher in the uninfused group. This stability was, however, reversed when lactose infusion was stopped which resulted in the fact that there was no significant difference in this parameter in both groups during the AL-infusion period. Sialidases are produced by trypanosomes (Esievo 1979, 1980; Pereira 1983; Pereira \& Hoff 1986; Engstler, Reuter \& Schauer 1991; Engstler \& Schauer 1993) which desialylate erythrocytes and hosts' cells (Esievo, Saror, llemobade \& Hallaway 1982; Pereira \& Hoff 1986). The desialylated erythrocytes become bound to $\beta$-D-galactose-specific lectins on the surfaces of macrophages (Kuster \& Schauer 1981; Muller et al. 1983) and subsequently become phagocytosed. Similarly, in the blood stream, such erythrocytes are also rapidly sequestrated (Durocher et al. 1975; Jancik, Schauer, Andres \& Van During 1978; Muller et al. 1981). Ibrahim (1997) showed that lactose in vitro inhibited binding and phagocytosis of desialylated erythrocytes by homologous isolated Kupffer cells isolated from the liver of goats and cattle. Thus, it can be deduced that the infused lactose in the $T$. vivax-infected bulls in this study prevented, or at least reduced, the binding and sequestration of desialylated circulating erythrocytes by the cells of the mononuclear phagocyte system. Hence, the life-span of the erythrocytes was prolonged as is shown by the relatively stabilized PCV up to Day 5 p.i. in the infected, infused group. The rate of change in PCV was significantly reduced up to Day 17 p.i. (Day 5) after lactose infusion was stopped, indicating that the declining plasma lactose was able to stablize the PCV compared to the uninfused group. The last 2 days of the after infusion period (Days 18 and 19 p.i.), however, when the level of decline in PCV was higher in the infused group, could have been due to very low levels of plasma lactose.
Therefore, it can be inferred that lactose in normal saline is able to inhibit early onset of anaemia in $T$. vivax-infected cattle. As lactose is used as an excipient in the pharmaceutical industry (Reynolds 1993), it could be beneficial in the treatment of trypanosomosis.

\section{ACKNOWLEDGEMENTS}

This study was partly funded by the Ahmadu Bello University Board of Research. We thank the late Malam Gidado Usman who took care of the experimental animals.

\section{REFERENCES}

CHATFIELD, C. 1983. Statistics for technology; a course in applied statistic, $3^{\text {rd }}$ ed. London: Chapman and Hall.

COLES, E.H. 1986. Veterinary clinical pathology, $4^{\text {th }}$ ed. Philadelphia: W.B. Saunders.

CROSS, G.A.M. \& JOHNSON, J.G. 1976. Structure and organisation of the variant-specific antigens of Trypanosoma bru$\mathrm{cei}_{2}$ in Biochemistry of parasites and host-parasite relationships, edited by $\mathrm{H}$. van den Bosche. Amsterdam: Elsevier.

DARGIE, J.D. 1978. Effects of Trypanosoma congolense and Trypanosoma brucei on the circulatory volumes of cattle, in Pathogenicity of trypanosomes, edited by G. Losos \& A. Chouinard. Ottawa: International Development Research Centre.

DUROCHER, J.R., PAYNE, R.C. \& CONRAD, M.E. 1975. Role of sialic acid in erythrocyte survival. Blood, 45:11-20.

ENGSTLER, M. \& SCHAUER, R. 1993. Sialidases from African trypanosomes. Parasitology Today, 9:222-225.

ENGSTLER, M., REUTER, G. \& SCHAUER, R. 1991. Partial purification and characterization of a sialidase from Trypanosoma brucei. Glycoconjugate Journal, 8:269.

ESIEVO, K.A.N. 1979. In vitro production of neuraminidase (sialidase) by Trypanosoma vivax. Proceedings of the $16^{\text {th }}$ meeting of the OAU/STRC International Council for Trypanosomiasis Research and Control, Yaounde, Cameroon, 1979: 205-210.

ESIEVO, K.A.N. 1980. Studies on an aspect of the anaemia of bovine trypanosomiasis (T. vivax) Ph.D. thesis, Ahmadu Bello University.

ESIEVO, K.A.N., SAROR, D.I., ILEMOBADE, A.A. \& HALLAWAY, M.H. 1982. Variation in erythrocyte surface and free serum sialic acid concentrations during experimental Trypanosoma vivax infection in cattle. Research in Veterinary Science, 32: $1-5$.

ESIEVO, K.A.N. 1983. Trypanosoma vivax, stock V953: Inhibitory effect of Type A influenza virus anti-HAV 8 serum on in vitro neuraminidase (sialidase) activity. Journal of Parasitology, 69:491-495.

ESIEVO, K.A.N., JAYE, A., ANDREW, J.N., UKOHA, A.I., ALAFIYATAYO, R.A., EDUVIE, L.O., SAROR, D.I. \& NJOKU, C.O. 1990. Electrophoresis of bovine erythrocyte sialic acids. Existence of additional band in trypanotolerant N'Dama cattle. Journal of Comparative Pathology, 102:357-361. 
FATIHU, M.Y., ADAMU, S., UMAR, I.A., IBRAHIM, N.D.G., EDUVIE, L.O. \& ESIEVO, K.A.N. 2008a. Studies on effects of lactose on experimental Trypanosoma vivax infection in Zebu cattle.1. Plasma kinetics of intravenously administered lactose at onset of infection and pathology. Onderstepoort Journal of Veterinary Research, 75:163-172.

FIENNES, R.N.T.W. 1950. The cattle trypanosomiasis: Some considerations of pathology and immunity. Annals of Tropical Medicine and Parasitology, 44:42-54.

HARPER, W.M. 1991. Statistics, $6^{\text {th }}$ ed. London: Pitman.

HOLMES, P.H. \& JENNINGS, F.W. 1976. The effect of treatment on the anaemia in African trypanosomiasis, in Pathophysiology of parasitic Infection, edited by E.J.L. Soulsby. New York: Academic Press.

HORNBY, H.E. 1921. Trypanosomes and trypanosomiasis of cattle. Journal of Comparative Pathology, 34:11-240.

IBRAHIM, N.D.G. 1997. The role of Kupffer cell surface lectin in erythrophagocytosis, in bovine Trypanosoma vivax-infection Ph.D. thesis, Ahmadu Bello University.

JANCIK, J., SCHAUER, R., ANDRES, K. H. \& VAN DURING, M. 1978. Sequestration of neuraminidase-treated erythrocytes: studies on its topographic, morphologic and immunologic aspects. Cell and Tissue Research, 186:209-226.

JANCIK, J. \& SCHAUER, R. 1974. Sialic acid a determinant of the life-time of rabbit erythrocytes. Hoppe-Seyler's Zeitschrift für Physologisch Chemie, 355:395-400.

JENNINGS, F.W., MURRAY, P.K., MURRAY, M. \& URQUHART, G.M. 1974. Anaemia in trypanosomiasis: Studies in rats and mice infected with Trypanosoma brucei. Research in Veterinary Science, 16:70-76.

KELM, S. \& SCHAUER, R. 1986. The galactose recognizing system of rat peritoneal macrophages. Receptor-mediated binding and uptake of glyco-proteins. Hoppe-Seyler's Zeitschrift für Physiologisch Chemie, 367:989-998.

KELM, S., JIBRIL, S., LEE, H., YOSHINO, T. \& SCHAUER, R. 1986a. The galactose receptor of rat peritoneal macrophages binding of sialidase-treated blood cells and glycoproteins, in Lectins $V$, edited by T.C. Bog-Hanse \& E. van Driessche. Berlin: Walter De Gruyter \& Co.

KELM, S., SHUKLA, A.K., PAULSON, J.C \& SCHAUER, R. 1986b. Reconstitution of the masking effect of sialic acid groups on sialidase-treated erythrocytes by the action of sialytransferase. Carbohydrate Research, 149:59-64.

KOBAYASHI, A., TIZZARD, I.R. \& WOO, P.T.K. 1976. Studies on the anaemia in experimental African trypanosomiasis. II. The pathogenesis of the anaemia in calves infected with Trypanosoma congolense. American Journal of Tropical Medicine and Hygiene, 25:401-406.

KOLB, H. \& KOLB-BACHOFEN, V. 1978. A lectin-like receptor on mammalian macrophages. Biochemical and Biophysical Research Communications, 85:678-683.

KOLB, H., VOGT, D., HERBERTZ, L., CORFIELD, A.P., SCHAUER, R. \& SCHLEPPER-SCHAFER, J. 1980. The galactosespecific lectins on rat hepatocytes and Kupffer cells have identical binding characteristics. Hoppe-Seyler's Zeitschrift für Physiologisch Chemie, 361:1747-1750.

KUSTER, J.M. \& SCHAUER, R. 1981. Phagocytoses of sialidasetreated rat erythrocytes. Evidence for a two-step mechanism. Hoppe-Seyler's Zeitschrift für Physiologisch Chemie, 362: 1507-1514.

LUCKINS, A.G. 1992. Protozoal diseases of camels. Proceedings of the First International Camel Conference, United Arab Emirates, 1992: 23-27.
MAMO, E., HOLMES, P.K. \& LEMMA, A. 1977. Some aspects of the anaemia in bovine trypanosomiasis. II. Erythrocytes survival studies in cattle infected with Trypanosoma congolense using ${ }^{51} \mathrm{Cr}$-labelled red blood cells. Ethiopian Veterinary Bulletin, 3:15-25.

MAMO, E. \& HOLMES, P.K. 1975. The erythrokinetics of Zebu cattle chronically infected with Trypanosoma congolense. Research in Veterinary Science, 18:105-106.

MULLER, E., SCHRODER, C., FRANCO, M.W., SHUKLA, A.K. \& SCHAUER, R. 1983. Involvement of a $\beta$-galactose-specific macrophage lectin in binding and erythrophagocytosis of erythrocytes, in Lectins III, edited by T.C. Bog-Hansen \& G.A. Spendler. Berlin: Walter de Gruyter and Co.

MULLER, E., FRANCO, M.W. \& SCHAUER, R. 1981. Involvement of membrane galactose in the in vivo and in vitro sequestration of desialylated erythrocytes. Hoppe-Seyler's Zeitschrift für Physiologisch Chemie, 36:1615-1620.

MURRAY, M. 1974. The pathology of African trypanosomiasis, in Progress in immunology II, edited by L. Brent L \& J. Holbrow. Amsterdam: North Holland Publishing Co.

MURRAY, M., TRAIL, J.C.M., TURNER, D.A. \& WISSOCQ Y. 1983. Livestock productivity and trypanotolerance. AddisAbaba: International Livestock Centre for Africa.

NOK, A.J. \& BALOGUN, E.O. 2003. A bloodstream Trypanosoma congolense sialidase could be involved in anemia during experimental trypanosomiasis. Journal of Biochemistry, 133: 725-730.

PEREIRA, M.E.A. 1983. A developmentally regulated neuraminidase activity in Trypanosoma cruzi. Science, 219:14441446.

PEREIRA, M.E.A. \& HOFF, R. 1986. Heterogenous distribution of neuraminidase activity in strains and clones of Trypanosoma cruzi and its possible association with parasite myotropism. Molecular and Biochemical Parasitology, 20:183-189.

PHILLIPS, O.S. 1978. Basic statistics for health science students. San Francisco: W.H. Freeman \& Co.

REYNOLDS, J.F.D. (Ed.) 1993. Martindale extra pharmacopoea. London: Pharmaceutical Press.

SAROR, D.I. 1980. Observations on the course and pathology of Trypanosoma vivax in Red Sokoto goats. Research in Veterinary Science, 28:36-38.

SCHLEPPER-SCHAFER, J., KOLB-BACHOFAN, V. \& KOLB, H. 1981. Analysis of lectin-dependent recognition of asialoerythrocytes by Kupffer cells. Biochemical Journal, 186:827831.

UMAR, I.A., OMAGE, J.J., SHUGABA, A., IGBOKWE, D.A., KWANASHIE, H.O., AGBEDE, R.I.S., SAROR, D.I. \& ESIEVO, K.A.N. 1998. Effects of acute bovine trypanosomosis (Trypanosoma vivax) on plasma kinetics of intravenously administered lactose. Veterinary Parasitology, 74:173-178.

VICKERMAN, K., SLESS, F., WENDY, H. \& EDWARDS, R.G. 1976. Some aspects of parasitaemic remission in experimental Trypanosoma brucei infections, in Biochemistry of parasites and host-parasite relationships, edited by $\mathrm{H}$. van den Bossche. Amsterdam: North-Holland Publishing Co.

VON BRAND, T. 1973. Biochemistry of parasites, $2^{\text {nd }}$ ed. New York: Academic Press.

WOODRUFF, A.W., ZIEGLER, J.L., HATHAWAY, A. \& GWATA, T. 1973. Anaemia in African trypanosomiasis and "Big Spleen Disease" in Uganda. Transactions of the Royal Society for Tropical Medicine and Hygiene, 67:329-337. 